\title{
Differential expression of rat pancreatic islet Beta-cell glucose transporter (GLUT 2), proinsulin and islet amyloid polypeptide genes after prolonged fasting, insulin-induced hypoglycaemia and dexamethasone treatment
}

\author{
L. Koranyi ${ }^{1}$, R. Bourey ${ }^{1}$, J. Turk ${ }^{2}$, M.Mueckler ${ }^{3}$ and M.A.Permutt ${ }^{1}$ \\ ${ }^{1}$ Department of Internal Medicine, Metabolism Division, ${ }^{2}$ Division of Clinical Chemistry, and ${ }^{3}$ Division of Cell Biology, Washington \\ University School of Medicine, St. Louis, Missouri, USA
}

\begin{abstract}
Summary. The question posed by these studies was whether chronic adaptive changes in glucose-stimulated insulin secretion are accompanied by comparable changes in islet Betacell glucose transporter (GLUT 2) gene expression. Control, fasted (3-day), insulin-injected hypoglycaemic (5-day), and dexamethasone-treated (4-day) rats $(n=5$ for each condition), were studied. After fasting significant decrements in proinsulin $\mathrm{mRNA} / \mu \mathrm{g}$ RNA $(-32 \%, p<0.05)$ and islet amyloid polypeptide mRNA/ug RNA $(-44 \%, p<0.05)$ were observed, while there was no change in GLUT $2 \mathrm{mRNA} / \mu \mathrm{g}$ RNA $(-13 \%, p>0.05)$. After insulin-induced hypoglycaemia, decrements in proinsulin mRNA/ $\mu \mathrm{g}$ RNA $(-49 \%$, $p<0.01)$ and islet amyloid polypeptide mRNA/ $\mu \mathrm{g}$ RNA $(-44 \%, p<0.01)$ were also observed, with no change in islet GLUT 2 mRNA/ $\mu$ g RNA $(-18 \%, p>0.05)$. Dexamethasone treatment resulted in a marked stimulatory effect on proinsulin mRNA/ $/ \mathrm{g}$ RNA $(+236 \%, p<0.001)$ and islet amyloid polypeptide mRNA/ $\mu \mathrm{g}$ RNA $(+221 \%, p<0.01)$, while again there was no change in islet GLUT $2 \mathrm{mRNA} / \mu \mathrm{g}$
\end{abstract}

RNA $(+0.3 \%, p>0.05)$. Quantitative immunoblot analysis with a GLUT 2 specific antibody revealed no change in islet GLUT 2 protein with fasting, but a small decrease $(-39 \pm 11 \%)$ in islet GLUT $2 / \mu \mathrm{g}$ protein after insulin-induced hypoglycaemia. These results do not support the hypothesis that chronic changes in glucose-stimulated insulin secretion are accompanied by changes in GLUT 2 expression. In contrast to the lack of correlation with GLUT 2, there was a striking correlation between proinsulin and islet amyloid polypeptide mRNAs for all experimental conditions $(r=0.974, p<0.001)$. These results suggest common transcriptional or turnover regulatory mechanisms or both for proinsulin and islet amyloid polypeptide gene expression, which differ for GLUT 2 gene expression.

Key words: Proinsulin, islet amyloid polypeptide mRNA, islet glucose transporter (GLUT 2) mRNA, Western blots, fasting, insulin-induced hypoglycaemia, dexamethasone.
Both transport and utilization of glucose are required for glucose sensing by pancreatic islet Beta cells $[1,2]$. Islet glucose transport differs from that in peripheral tissues in that it is mediated by a high- $\mathrm{K}_{\mathrm{m}}(40-60 \mathrm{mmol} / \mathrm{l})$ glucose transporter (GLUT 2) that is not saturated at physiological plasma glucose concentrations [3-5]. After entry into the cell, glucose is phosphorylated by glucokinase (ATP:D-hexose 6-phosphotransferase, EC 2.7.1.1), an enzyme that also has a $K_{m}$ in the physiological range of plasma glucose concentrations $(5-15 \mathrm{mmol})[6,7]$. The presence of GLUT 2 and glucokinase proteins enable islet Beta-cell glucose metabolism to vary in accordance with plasma glucose levels, an essential component of glucosestimulated insulin biosynthesis and secretion.

Chronic adaptive changes in islet GLUT 2 may be responsible for different islet Beta-cell responses to glucose after prolonged periods of islet suppression or stimulation [8]. Fasting in rats has been shown to result in diminished islet glucose transport, glucose utilization, and glucosestimulated insulin secretion [1,2], yet islet Beta-cell GLUT 2 studies in fasted rats are limited [9]. Chronic insulin-induced hypoglycaemia, like fasting, is also associated with marked suppression of islet Beta-cell function [10-12]. Rats chronically infused with insulin were observed to have marked suppression of GLUT 2 mRNA signal intensities relative to controls [13], assessed by in situ hybridization [14]. In contrast to the diminished glucose-signalling in islets from fasted or hypoglycaemic animals, animals chronically treated with glucocorticoid hormones exhibit enhanced insulin biosynthesis $[15,16]$ and glucose-stimulated insulin secretion $[17,18]$. GLUT 2 gene expression has not been evaluated following glucocorticoid treatment.

The hypothesis tested by the current study was that chronic adaptive changes in islet glucose metabolism and glucose-stimulated insulin secretion would be accompa- 
nied by comparable changes in islet GLUT $2 \mathrm{mRNA}$ and protein. We chose conditions known to result in alterations in insulin secretion, including a 3 -day fast $[1,2]$, 5 days of insulin-induced hypoglycaemia $[11,12]$, and 4 days of dexamethasone treatment [16-18]. Changes in GLUT 2 gene expression were measured relative to proinsulin and islet amyloid polypeptide genes. Striking changes and correlations between proinsulin and islet amyloid polypeptide gene expression were found for all conditions, while there was little chronic adaptive change for the islet GLUT 2 gene.

\section{Materials and methods}

\section{Animals}

Male Sprague-Dawley rats (150-200 g, SASCO, Omaha, Neb., USA) were caged in groups of five and fed a standard diet of rat chow (Ralston Purina, St.Louis, Mo., USA) and tap water ad libitum, except as described. The animals were exposed to light between 08.00 hours and 20.00 hours daily. After 7 days of adaptation to our animal facility, the animals were divided into the following experimental groups: control, insulin-injected hypoglycaemic, fasted, and dexamethasone-treated.

Hypoglycaemia was produced by two daily insulin injections $(1 / 3$ volume:2/3 volume mixture of NPH and Ultra-lente; Squibb-Novo, Princeton, NJ, USA, $40 \mathrm{U} / \mathrm{kg}$ body weight) for 5 days. Blood glucose levels were determined three times a day using Dextrostix strips and a Glucometer (Ames, Miles Laboratories, Elkhart, Ind., USA) and the insulin dose was adjusted $\left(+5 \mathrm{U} \cdot \mathrm{kg}\right.$ body weight ${ }^{-1}$. day) to maintain the blood glucose levels at $2.8-3.9 \mathrm{mmol} /$.

Rats in the dexamethasone-treated group were injected twice daily with $0.125 \mathrm{mg} / \mathrm{kg}$ body weight of dexamethasone phosphate (Dexamethasone; Elkins-Sins Inc., Cherry Hill, NJ, USA) for 4 days. Blood glucose levels were measured daily. Animals in one group were individually housed and fasted for 3 days prior to analysis.

\section{Measurement of blood parameters}

Serum insulin concentrations were determined by a double antibody radioimmunoassay using rat insulin standards (Novo, Copenhagen, Denmark) and plasma glucose by a glucose oxidase method using a Beckman Glucose Analyzer-2 (Beckman Instruments, Fullerton, Calif., USA).

\section{Determination of insulin-, islet amyloid polypeptide-, and GLUT 2-mRNAs}

Animals were killed by pentobarbital sodium anaesthesia (100 $\mathrm{mg}$ Nembutal/kg body weight; Abbott Laboratories, North Chicago, Ill., USA). Before cardiorespiratory arrest, blood was collected from the tail vein, the abdomen was dissected, and pancreas and liver were excised and frozen in liquid nitrogen.

Total tissue RNA was extracted with a guanidine thiocyanate water-saturated phenol extraction method [19]. For extraction of RNA from pancreas containing high amounts of RNAse, a modification was introduced. Pancreata were homogenized in $4 \mathrm{~mol} / \mathrm{l}$ guanidine thiocyanate containing $1 \%$ of octylphenol-ethylene oxide detergent (Nonidet P-40; Sigma, St.Louis, Mo., USA), and following a centrifugation $\left(3500 \mathrm{~g}\right.$ for $5 \mathrm{~min}$ at $10^{\circ} \mathrm{C}$ ) $1 / 20$ volumes (v) of $2 \mathrm{~mol} / 1 \mathrm{KOAc}(\mathrm{pH} 5.0), 1 / 12.5 \mathrm{v}$ of $1 \mathrm{~mol} / 1 \mathrm{HOAc}$ and $1.5 \mathrm{v}$ of absolute ethanol were added to the supernatant. After precipitation $(4 \mathrm{~h}$ at $-20^{\circ} \mathrm{C}$ ) and centrifugation $\left(15000 \mathrm{~g}\right.$ for $10 \mathrm{~min}$ at $+4^{\circ} \mathrm{C}$ ) the pellet was homogenized in $6 \mathrm{~mol} / \mathrm{l}$ guanidine $\mathrm{HCl}$ (containing $0.1 \mathrm{~mol} / \mathrm{l}$
KOAc $\mathrm{pH} 5.0,0.025 \mathrm{~mol} / 1 \mathrm{EDTA}, 0.1 \mathrm{~mol} / \mathrm{l} 2-\beta$-mercapto ethanol) and precipitated with $0.5 \mathrm{v}$ of ethanol $\left(-20^{\circ} \mathrm{C}\right.$, overnight $)$. The samples were centrifuged at the same speed and the pellets were dissolved in $6 \mathrm{~mol} / /$ guanidine $\mathrm{HCl}$ and multiple water-saturated phenol/phenol-chloroform-isoamylalcohol/chloroform extractions and ethanol precipitation were performed. After determining the $a b$ sorbance at 260 and $280 \mathrm{~nm}$, aliquots of RNA were electrophoresed on a mini-gel to verify the in tegrity of RNA preparations. The $\mathrm{A}_{2602280}$ ratios and the 28S/18S RNA ratios were less than 2 for all samples.

DNA concentrations of tissue homogenates were measured with a TKO 100 DNA fluorometer (Hoefer Scientific Instruments, San Francisco, Calif., USA) with Hoechst 33258 dye (Poly-Sciences, Warrington, Pa., USA) and calf thymus DNA (Sigma) as standard. Probes and synthetic mRNA standards used for study were:

1. rat proinsulin I cDNA fragment: 304 base pairs (bp) of coding information [20].

2. rat GLUT 2 cDNA: isolated from a rat liver cDNA library with a human GLUT 2 clone [21]. Sequence analysis indicated that the 2.2 kilobase (kb) rat GLUT 2 cDNA was identical to that of the published rat GLUT 2 clone [22]. For RNA protection analysis a $529 \mathrm{bp}$ fragment of the coding region was subcloned into pGEM-1 (Promega, Madison, Wis., USA).

3. 1-441 bp fragment of rat islet amyloid polypeptide cDNA (kindly provided by Prof. D.F.Steiner, University of Chicago, Chicago, Ill., USA) in pGEM-4Z vector (Promega) [23]

Synthetic insulin, islet amyloid polypeptide, and GLUT 2 mRNA standards and uniformly labelled [ $\left.{ }^{32} \mathrm{P}\right] \mathrm{CRNA}$ probes were transcribed according to a protocol as previously described [24].

Isolation of poly(A) RNA by oligo-dT chromatography and Northern blot analysis were performed by standard procedures [25]. RNA $(20 \mu \mathrm{g})$ or poly(A) RNA $(5-10 \mu \mathrm{g})$ was electrophoresed on $1.0 \%$ agarose-formaldehyde gels, blotted to Nytran (Scheicher \& Schuell, Keene, NH, USA) nylon membranes, and hybridized to appropriate probes. Pre-hybridization and hybridization were done under high stringency conditions as described in the conditions for Dot blot hybridization.

\section{Dot blot hybridization assay}

Ribonuclease protection assays were used to measure less abundant GLUT 2 mRNA in pancreatic RNA, while dot blot hybridization was used to measure more abundant proinsulin and islet amyloid polypeptide mRNAs in pancreas, and GLUT $2 \mathrm{mRNA}$ in isolated islets and in liver. Aliquots of RNA ( 5.0 and $10.0 \mu \mathrm{g})$ were dissolved in $5.6 \%$ formaldehyde, $10 \times \mathrm{SSC}\left(1.5 \mathrm{~mol} / 1 \mathrm{NaCl}, 0.15 \mathrm{~mol} / 1 \mathrm{Na}_{3} \mathrm{ci}-\right.$ trate $2 \mathrm{H}_{2} \mathrm{O}, \mathrm{pH} 7.0$ ) and blotted onto nylon membranes (Nytran). Membranes were incubated with the appropriate probes $\left(-5 \times 10^{6} \mathrm{cpm} / \mathrm{ml}\right)$ for $18 \mathrm{~h}$ at $60^{\circ} \mathrm{C}$ in $50 \%$ formamide, $5 \times \mathrm{SSPE}$ $\left(0.75 \mathrm{~mol} / 1 \mathrm{NaCl}, 50 \mathrm{mmol} / 1 \mathrm{NaH}_{2} \mathrm{PO}_{4}, 5 \mathrm{mmol} / \mathrm{l}\right.$ EDTA $), 2.5 \times$ Denhardt's, $0.1 \%$ sodium dodecyl sulphate (SDS) and then washed in $0.1 \times \mathrm{SSC}, 0.1 \%$ SDS at $65^{\circ} \mathrm{C}$. The blots were exposed to Kodak XAR-5 film (Rochester, NY, USA) at $-70^{\circ} \mathrm{C}$ using intensifying screens (Cronex Lightening Plus, DuPont, Wilmington, Del., USA) for various periods of time. The amounts of proinsulin, islet amyloid polypeptide, and GLUT 2 mRNA were quantitated against dilutions of a known amount of appropriate synthetic mRNA standards as described [24].

\section{Ribonuclease protection analysis}

Aliquots of total pancreatic RNA $(50 \mu \mathrm{g})$ were hybridized overnight in $60 \%$ formamide, $0.4 \mathrm{~mol} / 1 \mathrm{NaCl}, 0.04 \mathrm{~mol} / 1$ PIPES (piperaine$\mathrm{N}, \mathrm{N}$ '-bis(2-ethanesulfonic acid)), pH 6.4, $1 \mathrm{mmol} / 1$ EDTA with $5-10 \times 10^{6} \mathrm{cpm}$ freshly labelled cRNA probes at $45^{\circ} \mathrm{C}$. Samples were digested with $40 \mu \mathrm{g} / \mathrm{ml}$ boiled ribonuclease $A$ and $2.0 \mu \mathrm{g} / \mathrm{ml}$ ribonu- 
Table 1. Effects of experimental conditions on body weight, plasma glucose, and serum insulin

\begin{tabular}{lcccl}
\hline $\begin{array}{l}\text { Experimental } \\
\text { condition }\end{array}$ & $n$ & $\begin{array}{l}\text { Body weight } \\
\text { change } \\
(\mathrm{g})\end{array}$ & $\begin{array}{l}\text { Plasma } \\
\text { glucose } \\
(\mathrm{mmol} / \mathrm{l})\end{array}$ & $\begin{array}{l}\text { Serum } \\
\text { insulin } \\
(\mu \mathrm{g} / \mathrm{l})\end{array}$ \\
\hline $\begin{array}{l}\text { Control } \\
\text { Fasted }\end{array}$ & 5 & $80.6 \pm 4.7$ & $13.4 \pm 1.3$ & $1.95 \pm 0.31$ \\
$\begin{array}{l}\text { Insulin- } \\
\text { injected }\end{array}$ & 5 & $-52.0 \pm 1.6^{\mathrm{c}}$ & $9.4 \pm 1.2^{\mathrm{a}}$ & $0.32 \pm 0.12$ \\
$\begin{array}{l}\text { Dexametha- } \\
\text { sone-treated }\end{array}$ & 5 & $28.8 \pm 3.1^{\mathrm{c}}$ & $13.1 \pm 1.0$ & $6.34 \pm 1.00^{\mathrm{b}}$ \\
\hline
\end{tabular}

${ }^{a} p<0.05,{ }^{b} p<0.01,{ }^{\circ} p<0.001$ vs control. Values are the mean \pm SEM for the number of animals indicated

clease $\mathrm{T}_{1}$ (Sigma), ribonuclease was inactivated by $50 \mu \mathrm{g}$ Pro teinase K (Sigma), protected fragments were precipitated, electrophoresed on sequencing gels, and autoradiography performed as described previously [24]. GLUT 2 mRNA was quantified by hybridizing serial dilutions of known amounts of synthetic GLUT 2 and glucokinase mRNAs. The total RNA content of the synthetic RNA dilutions was equalized with brain RNA in the case of GLUT 2 and this RNA was also used as a negative control. The gels were dried, exposed to Kodak XAR-5 film at $-70^{\circ} \mathrm{C}$ using intensifying screens (Cronex Lightening Plus).

To quantitate GLUT $2 \mathrm{mRNA}$, the gels were fitted and fixed to the developed films, protected fragments (GLUT 2: $529 \mathrm{bp}$ ) were cut out and counted with scintillation fluid in a scintillation counter as described [24]. Equal areas away from the band of interest were excised and analysed to establish background. The intra-assay coefficient of variation for this technique was $11.9 \%$ (same sample in 10 adjacent lanes).

\section{Isolation of islets}

Tissue culture medium (CMRL-1066), penicillin, streptomycin, Hanks' balanced salt solution (HBSS), heat-inactivated fetal bovine serum (FBS), and L-glutamine were from Gibco (Grand Island, NY, USA). Pentex bovine serum albumin (BSA) (fatty acid free, fraction V) was obtained from Miles Laboratories. Islets were isolated aseptically from male Sprague-Dawley rats fed ad libitum, as described elsewhere [26]. In brief, the pancreas was inflated with HBBS (supplemented with $0.5 \%$ penicillin-streptomycin), excised, and freed from adherent lymphatic, vascular, and adipose tissue. The pancreatic tissue was then digested with collagenase obtained from Boehringer Mannheim (Indianapolis, Ind., USA) $\left(5 \mathrm{mg} / \mathrm{ml}\right.$ at $39^{\circ} \mathrm{C}$ for $12.5 \mathrm{~min}$ ), rinsed with $\mathrm{HBBS}$, and centrifuged on a discontinuous Ficoll (Sigma) gradient (four layers of $27 \%, 23 \%, 20.5 \%$, and $11 \%$ ). Islets were collected from the $11-20.5 \%$ interface and washed in CMRL-1066 tissue culture medium (supplemented with $1 \%$ penicillin-streptomycin, 10\% heat-inactivated fetal bovine serum (FBS), $1 \% \mathrm{~L}$-glutamine, and $5.55 \mathrm{mmol} / \mathrm{l} \mathrm{D-glucose}$ ). This procedure typically yielded 300 islets per rat.

\section{Quantitation of transporter protein by immunoblotting}

Islets were solubilized by resuspension in $0.5 \mathrm{~mol} / 1$ TRIS buffer (Tris(hydroxymethyl)amino methane) (pH 6.8) and 2\% SDS. The protein concentration was determined by a bicinchoninic acid assay system (Pierce, Rockford, Ill., USA) and samples were subjected to SDS-PAGE. Protein was electrophoretically transferred (Polyblot, ABN, Hayward, Calif., USA) to nitrocellulose paper. Nitrocellulose sheets were incubated with phosphate-buffered saline ( $\mathrm{pH}$ 7.4) containing $50 \mathrm{mg} / \mathrm{ml}$ powdered milk (Carnation Co., Los Angeles, Calif., USA) for $60 \mathrm{~min}$ at $22^{\circ} \mathrm{C}$, and thereafter with a polyclonal antibody specific for the 20 amino acid GLUT 2 carboxy terminus, and after washing, with ${ }^{125}$ I-labelled goat anti-rabbit antibody
(Amersham Corp., Arlington Heights, Ill., USA). Quantitation was performed by analysis of multiple samples from islet protein pooled from control $(n=6)$ and insulin-injected hypoglycaemic $(n=6)$ rats, followed by densitometric analysis of autoradiographs.

\section{Statistical analysis}

Differences among groups were examined by analysis of variance, and between groups by unpaired $t$-test where indicated. The correlations were determined by univariate linear regression analysis. Data were stored and analysed using the CLINFO Data Analysis System of Washington University (G.C.R.C. RR00036) supported by the Division of Research of the NIH, and with STATA2.05 (Computing Resource Center, Los Angeles, Calif., USA) program on a personal computer.

\section{Results}

\section{Effects of chronic treatments on body weight,} plasma glucose, and serum insulin

Control rats gained weight during the 5 days of observation, while rats fasted for 3 days lost weight (Table 1 , $p<0.001)$. Rats treated with insulin to induce chronic hypoglycaemia for 5 days (Table 1 ) gained more weight than control rats $(p<0.05)$, and rats treated with dexamethasone for 4 days gained less weight than control rats $(p<0.001)$. Failure to gain weight in dexamethasonetreated rats to the same degree as controls was probably due to the previously noted appetite suppressant effect of this dose of the drug [15].

Plasma glucose concentrations were lower in fasted rats $(p<0.05)$, and also lower in insulin-injected rats compared to that in control rats $(p<0.01)$ since these rats were injected with insulin specifically to achieve hypoglycaemia. Plasma glucose did not differ after 4 days of dexamethasone treatment, although previous studies had noted a transient rise in blood glucose one day after treatment [16]. Serum insulin concentrations tended to be suppressed in fasted rats, and were more than three-fold elevated $(p<0.01)$ in dexamethasone-treated rats relative to controls.

\section{Effects of chronic treatments on pancreatic/islet RNA}

Quantitation of islet mRNAs in whole pancreatic RNA. The effects of chronic treatments on islet-specific mRNAs were quantitated by dot blot analysis for the more abundant proinsulin and islet amyloid polypeptide mRNAs, or by a more sensitive ribonuclease protection assay for less abundant GLUT 2 mRNA. To illustrate that intact islet mRNAs were obtained, poly(A) RNA was isolated from total pancreatic RNA and subjected to Northern blot analysis with ${ }^{32}$ P-GLUT 2 cRNA (Fig. 1). A single major band of the predicted size $(2.8 \mathrm{~kb},[22])$ was readily detected in $10 \mu \mathrm{g}$ of poly(A) RNA.

These studies showed that GLUT 2 mRNA could be detected in Northern blots of poly(A)-enriched total pancreatic RNA. To avoid variable losses involved in poly(A) isolation however, more sensitive and readily 


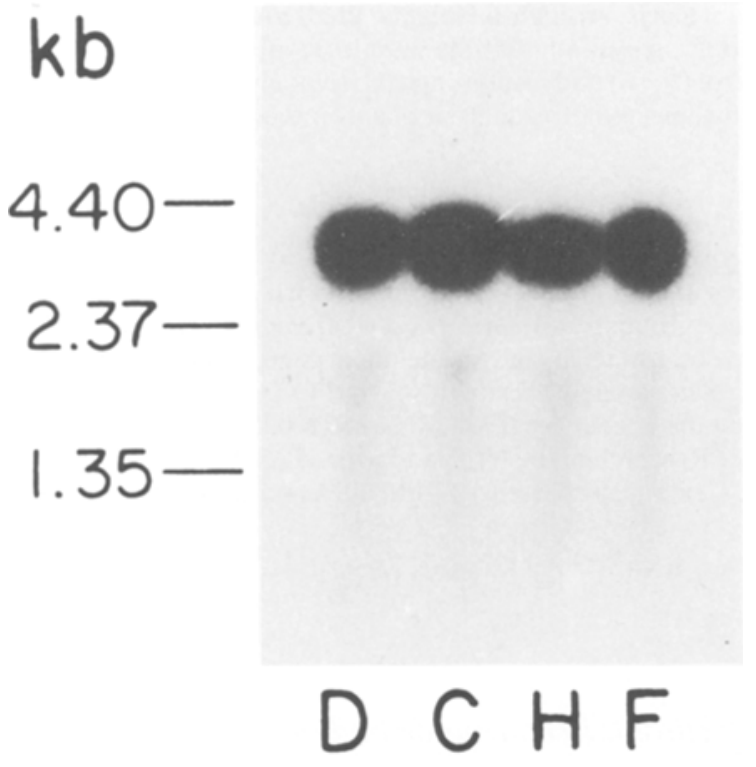

Fig.1. Northern blot analysis of pancreatic poly (A) RNA (10 $\mu \mathrm{g})$ from dexamethasone-treated (D), control (C), insulin-treated hypoglycaemic $(\mathrm{H})$, and fasted $(\mathrm{F})$ rats, hybridized with ${ }^{32} \mathrm{P}$-rat GLUT 2 cDNA probe. The mobilities of the RNA standards are indicated. $\mathrm{Kb}$, Kilobase

quantifiable ribonuclease protection assays were developed to measure this mRNA directly in total pancreatic RNA. A representative experiment measuring GLUT 2 mRNA in total liver RNA and pancreatic RNA along with synthetic GLUT 2 mRNA standards and controls is shown in Figure 2. The amount of protected ${ }^{32} \mathrm{P}$ GLUT 2 cRNA, identified as a 529 nucleotide fragment, was proportional to the amount of synthetic GLUT 2 mRNA hybridized (1-8 pg), while none was seen in brain. For this assay less than $1 \mathrm{pg}$ of GLUT 2 mRNA could be readily detected in $50 \mu \mathrm{g}$ of total pancreatic RNA. The lower abundance of GLUT 2 mRNA in pancreas vs liver is also illustrated.
Effects of treatments on proinsulin, islet amyloid polypeptide and GLUT 2 mRNAs - measurement in whole pancreas. The effects of fasting on pancreatic RNA are shown in Table 2. Fasting for 3 days resulted in a marked reduction in pancreatic RNA/DNA $(-64 \%, p<0.001)$, which was not surprising due to the known effect of fasting on ribosomal RNA [28]. The effects of fasting were not limited solely to pancreatic acinar RNA however, as in separate experiments we isolated islets from control and 3-day fasted rats, and measured RNA and DNA. The RNA/DNA ratio, determined on isolated islets from fasted rats, was reduced $(-42+6 \%, p<0.01)$ compared to that in control rats $(0.69+0.08$ vs $1.18+0.07$, fasted vs control respectively, $n=14$ rats for each group). The other treatments did not result in a significant change in pancreatic RNA, but insulin treatment did result in a decrease in islet RNA (Table 3).

The consequences of a 3-day fast on islet-specific mRNAs in total pancreatic RNA are shown in Table 2. There was no change in GLUT 2 mRNA/ $\mu \mathrm{g}$ RNA $(-13 \%, p>0.05)$, while both proinsulin mRNA/ $\mu \mathrm{g}$ RNA $(-32 \%, \quad p<0.05$ and islet amyloid polypeptide mRNA/ $\mu \mathrm{g}$ RNA $(-44 \%, p<0.05)$ were reduced. After 5 days of insulin-induced hypoglycaemia, like the response to fasting there was no significant change in GLUT 2 mRNA/ $\mu$ g RNA $(-18 \%, p>0.05)$, while there were significant decrements in proinsulin mRNA $/ \mu \mathrm{g}$ RNA $(-49 \%, p<0.01)$ and islet amyloid polypeptide mRNA/ $/ \mu \mathrm{g}$ RNA $(-44 \%, p<0.01)$. Dexamethasone treatment resulted in a marked stimulatory effect on proinsulin $\mathrm{mRNA} / \mu \mathrm{g}$ RA $(+236 \%, p<0.001)$ and islet amyloid polypeptide mRNA/ $\mu \mathrm{g}$ RNA ( $+221 \%$, $p<0.01$ ), while again there was no change in islet GLUT 2 mRNA $/ \mu \mathrm{g}$ RNA $(+0.3 \%, p>0.05)$.

Quantitation ofmRNAs in isolated islets. To confirm the results of islet GLUT 2 mRNA measurements in whole pancreatic RNA, islets were isolated from chronically treated rats, and RNA analysed (Table 3 ). Total islet RNA was

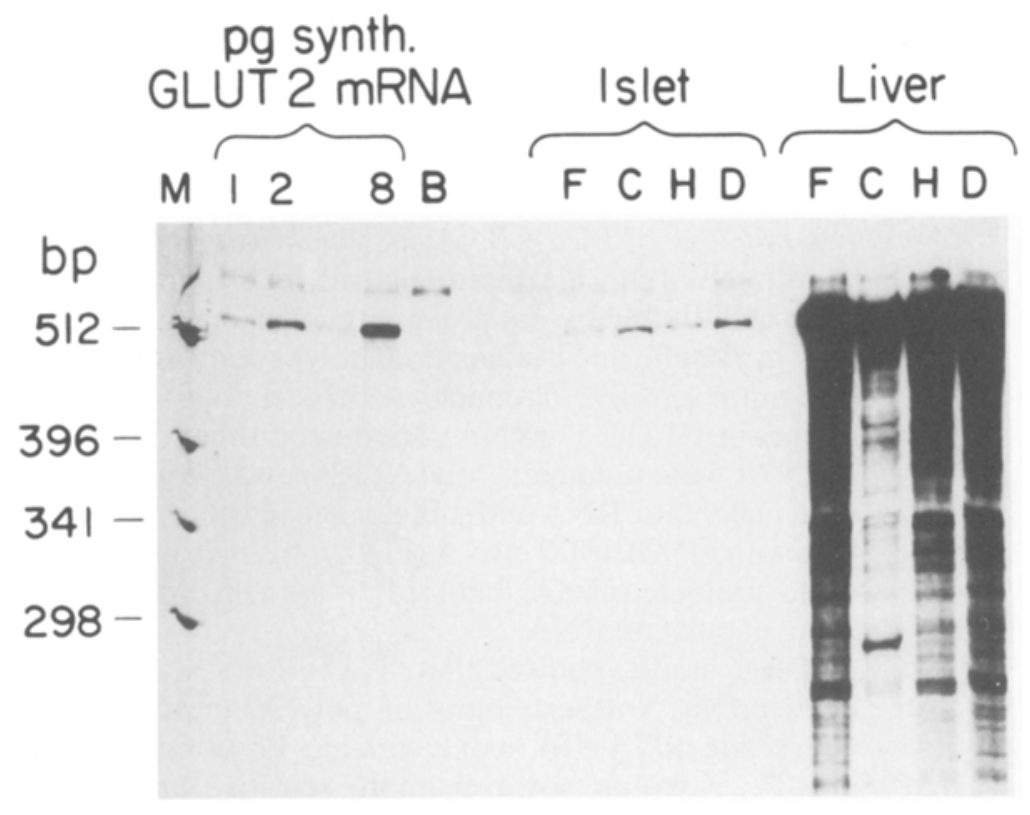

Fig. 2. Quantitation of pancreatic GLUT $2 \mathrm{mRNA}$ by ribonuclease protection assay. Increasing amounts of synthetic GLUT 2 mRNA (lanes marked 1, 2, and $8 \mathrm{pg}$ ), $50 \mu \mathrm{g}$ of pancreatic RNA (islet) from individual fasted $(\mathrm{F})$, control (C), insulin-treated hypoglycaemic $(\mathrm{H})$, and dexamethasone-treated (D) rats, $50 \mu \mathrm{g}$ of rat brain RNA (B), and $50 \mu \mathrm{g}$ of liver RNA from animals treated as indicated, were hybridized to rat ${ }^{32}$ P GLUT 2 cRNA probe. The protected $529 \mathrm{bp}$ bands were cut out and counted as described in Materials and methods. The faint band of larger size is the template not completely digested by DNAse. M refers to a ${ }^{35} \mathrm{~S}-1$ kilobase ladder (BRL) as a marker. bp, Base pairs 
Table 2. Effects of experimental conditions on islet mRNAs measured in total pancreatic RNA

\begin{tabular}{|c|c|c|c|c|}
\hline $\begin{array}{l}\text { Experi- } \\
\text { mental } \\
\text { condition }\end{array}$ & RNA/DNA & 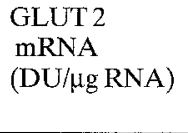 & 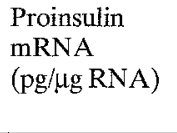 & $\begin{array}{l}\text { Islet amyloid } \\
\text { polypeptide } \\
\text { mRNA } \\
\text { (pg/ } / \mathrm{g} \text { RNA) }\end{array}$ \\
\hline Control & $2.03 \pm 0.23$ & $3.50 \pm 0.32$ & $2.03 \pm 0.18$ & $0.61 \pm 0.06$ \\
\hline Fasted & $0.74 \pm 0.15^{c}$ & $3.06 \pm 0.85$ & $1.38 \pm 0.19^{\mathrm{a}}$ & $0.34 \pm 0.06^{\mathrm{a}}$ \\
\hline $\begin{array}{l}\text { Insulin- } \\
\text { injected }\end{array}$ & $1.48 \pm 0.15$ & $2.87 \pm 0.21$ & $1.03 \pm 0.12^{b}$ & $0.24 \pm 0.03^{\mathrm{b}}$ \\
\hline $\begin{array}{l}\text { Dexame- } \\
\text { thasone- } \\
\text { treated }\end{array}$ & $1.52 \pm 0.14$ & $3.51 \pm 0.31$ & $4.80 \pm 0.40^{c}$ & $1.35 \pm 0.15^{b}$ \\
\hline
\end{tabular}

${ }^{\mathrm{a}} p<0.05,{ }^{\mathrm{b}} p<0.01,{ }^{\mathrm{c}} p<0.001$ vs control. DU, Arbitrary densitometric units. Values are the mean $\pm \mathrm{SEM}, n=5$ animals for each experimental condition as in Table 1

Table 3. RNA analysis of isolated pancreatic islets

\begin{tabular}{|c|c|c|c|c|c|c|}
\hline & \multirow[t]{2}{*}{$n$} & \multicolumn{3}{|c|}{ RNA/DNA GLUT 2 mRNA } & \multicolumn{2}{|c|}{ Proinsulin mRNA } \\
\hline & & & $\begin{array}{l}(\mathrm{pg} / \mu \mathrm{g} \\
\text { RNA) }\end{array}$ & & & \\
\hline & 14 & $1.18 \pm 0.07$ & $56.5 \pm 9.2$ & $60.3 \pm 6.8$ & $0.70 \pm 0.05$ & $0.82 \pm 0.07$ \\
\hline Fasted & 14 & $0.69 \pm 0.08^{b}$ & $119.8 \pm 14.2^{\mathrm{b}}$ & $92.2 \pm 21.3$ & $0.37 \pm 0.05^{\mathrm{b}}$ & $0.27 \pm 0.05^{b}$ \\
\hline & 15 & $0.43 \pm 0.17^{b}$ & $472 \pm 234^{b}$ & $155 \pm 47^{\mathrm{b}}$ & $0.40 \pm 0.12^{\mathrm{a}}$ & $0.20 \pm 0.09^{b}$ \\
\hline
\end{tabular}

${ }^{\mathrm{a}} p<0.05,{ }^{\mathrm{b}} p<0.01$ vs control. DU, Arbitrary densitometric units. Values are mean \pm SEM for the number of animals indicated

markedly decreased in fasted $(-42 \%, p<0.01)$ and insulin-injected $(-64 \%, p<0.01)$ rats relative to that in control rats, so mRNA concentrations were expressed per $\mu \mathrm{g}$ islet RNA and per $\mu$ g islet DNA. As expected, and confirming previous reports [27], proinsulin $\mathrm{mRNA} / \mu \mathrm{g}$ islet RNA was reduced $47 \%(p<0.05)$ in fasted rats, and reduced $43 \%(p<0.01)$ in insulin-injected rats. In contrast, fasting induced an increase in GLUT $2 \mathrm{mRNA} / \mu \mathrm{g}$ islet RNA, but this difference was not apparent when GLUT 2 mRNA was expressed per $\mu$ g islet DNA (Table 3). Insulin injection induced a significant increase $(p<0.01)$ in GLUT 2 mRNA $/ \mu \mathrm{g}$ islet RNA, as well as per $\mu \mathrm{g}$ islet DNA $(+158 \%, p<0.01)$. Overall, there was no consistent correlation between proinsulin $m$ RNA and GLUT $2 \mathrm{mRNA}$ levels in pancreatic islets $(r=-0.16, p=0.53)$.

\section{Analysis of islet GLUT 2 protein}

To determine whether the lack of change in GLUT 2 mRNA following prolonged treatments noted above was accompanied by changes in the protein, islet GLUT 2 protein was assessed by quantitative immunoblot analysis with a GLUT 2 specific antibody, derived from the aminoterminus of a synthetic GLUT 2 peptide. This antiserum detected a single protein of approximately $48 \mathrm{kDa}$ in liver (not shown). The antiserum detected a somewhat larger protein in islet tissue $(52 \mathrm{kDa})$, as well as less prominent smaller proteins. The difference in size of liver and islet GLUT 2 proteins has been previously noted [40]. While we do not know the nature of the differences in mobility of the various antibody-reactive proteins, the antiserum is specific in that these bands are not observed in tissues other than liver or islets. As shown in Figure 3, multiple analyses $(n=6)$ of islet protein from islets pooled from six control and six hypoglycaemic rats showed a small reduction $(-39 \pm 11 \%)$ after 5 days of insulin-induced hypoglycaemia, although there was no significant effect of fasting on islet GLUT 2 protein.

\section{Effects of chronic treatments of GLUT 2 mRNA in liver}

Following 3 days of fasting, the RNA/DNA ratio in liver was reduced to one-third of that in controls $(p<0.01$, Table 4), consistent with previously reported effects of fasting on ribosomal RNA [28], while the other conditions had no significant effect on liver RNA. GLUT 2 $\mathrm{mRNA} / \mu \mathrm{g}$ RNA in liver was not affected by any of the experimental conditions.

\section{Correlation analysis}

The relationships between plasma glucose, serum insulin, and islet $\mathrm{mRNAs}$ under all experimental conditions were assessed by correlation analysis, and the results are shown in Table 5. The strongest positive correlation was between proinsulin and islet amyloid polypeptide mRNAs $(r=0.974, p<0.001)$. These mRNAs also exhibited significant positive correlations with both plasma glucose and serum insulin levels. In contrast, there were no correlations between islet GLUT 2 and the other two islet mRNAs, nor with blood glucose or serum insulin.

\section{Discussion}

Previous studies have shown that transformed islet cell lines, deficient in glucose-stimulated insulin secretion, exhibited impaired glucose transport and altered glucose

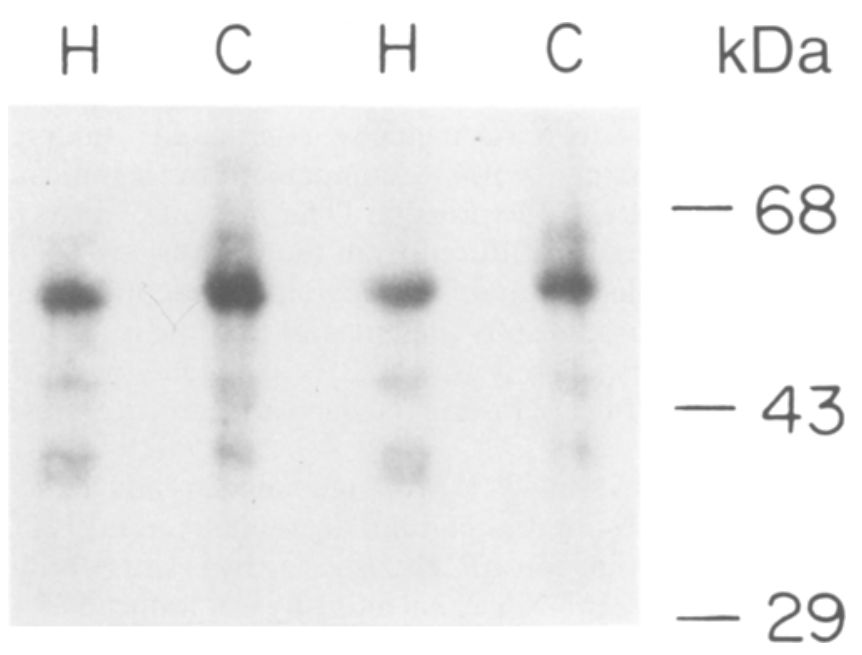

Fig.3. Quantitative immunoblot analysis of rat pancreatic islet protein from control (C) and 5-day insulin-injected hypoglycaemic (H) rats. Equal aliquots of protein $(50 \mu \mathrm{g})$ were electrophoresed, blotted to a nitrocellulose membrane, and reacted with a GLUT 2 specific antibody as described in the Materials and methods. These results were quantitated by densitometric analysis of multiple samples from pooled islets from either control $(n=6)$ or hypoglycaemic $(n=6)$ animals as described in Materials and methods 
Table 4. Effects of experimental conditions on liver RNA

\begin{tabular}{lcc}
\hline $\begin{array}{l}\text { Experimental } \\
\text { condition }\end{array}$ & RNA/DNA & $\begin{array}{l}\text { GLUT2 mRNA } \\
\text { (DU/ } \mu \text { RNA) }\end{array}$ \\
\hline Control & $1.64 \pm 0.26$ & $7.80 \pm 1.00$ \\
Fasted & $0.54 \pm 0.08^{\mathrm{a}}$ & $8.52 \pm 0.62$ \\
Insulin-injected & $1.78 \pm 0.18$ & $8.10 \pm 0.65$ \\
Dexamethasone-treated & $2.04 \pm 0.10$ & $10.27 \pm 0.85$ \\
\hline
\end{tabular}

${ }^{a} p<0.01$ vs control. Values are the mean \pm SEM for the same five animals in each condition as in Tables 1 and 2

Table 5. Correlation analysis

\begin{tabular}{lcllll}
\hline & Gluc & Ins & Proins & IAPP & iGLUT 2 \\
\hline Gluc & 1.000 & & & & \\
Ins & 0.259 & 1.000 & & & \\
Proins & $0.581^{\mathrm{b}}$ & $0.731^{\mathrm{b}}$ & 1.000 & & \\
IAPP & $0.508^{\mathrm{a}}$ & $0.701^{\mathrm{b}}$ & $0.974^{\mathrm{c}}$ & 1.000 & \\
iGLUT 2 & -0.142 & 0.125 & 0.021 & 0.134 & 1.000 \\
\hline
\end{tabular}

${ }^{\mathrm{a}} p<0.05 ;{ }^{\mathrm{b}} p<0.01,{ }^{\mathrm{c}} p<0.001 ; n=20$ for each correlation except Ins, where $n=15$ (no values for insulin-injected group). Gluc and Ins = plasma glucose and serum insulin respectively after treatment; Proins $=$ proinsulin, IAPP $=$ islet amyloid polypeptide, and iGLUT 2 = islet GLUT 2 mRNA/ $\mu$ RNA, respectively

transporter gene expression [29-31]. Because fasting is associated with impaired islet glucose transport and utilization, and impaired glucose-stimulated insulin secretion [1, 2], we sought to determine whether GLUT 2 gene expression was reduced after fasting. One study reported a reduction of GLUT 2 mRNA in whole pancreatic RNA from fasted rats [9]. Using a sensitive ribonuclease protection assay the results of the current study did not confirm this reduction. One explanation for different results between the two studies is that the previous study [9] treated rats for 3 months with a choline-copper deficient diet to induce $90 \%$ atrophy of pancreatic exocrine tissue. Furthermore, in the current study there was no change in GLUT 2 protein, measured by quantitative immunoblotting, following 3 days of fasting. These results combined suggest that the decrease in glucose-stimulated insulin secretion of fasting is not accompanied by significant changes in GLUT 2 expression. The lack of change in GLUT 2 noticeably differed from the obvious effects of fasting on proinsulin and islet amyloid polypeptide gene expression. These results thus suggest that the reduction in glucose transport reported $[1,2]$ is likely due to a posttranslational effect of fasting on glucose transporter function.

In a previous study [13] prolonged insulin-induced hypoglycaemia resulted in parallel decrements in GLUT2 mRNA and proinsulin mRNA, assessed by in situ hybridization. GLUT 2 mRNA signal intensity was reduced $85 \%$ compared to controls after 4-day infusion, suggesting that glucose transporter levels may be an important determinant of islet glucose metabolism. We therefore felt it necessary to confirm these results by alternative methods. Both studies showed a marked decrease in proinsulin mRNA as a result of insulin-induced hypoglycaemia. Our results differed, however, in that GLUT 2 mRNA concentration did not change when assessed by ribonuclease pro- tection assay on whole pancreatic RNA, and were found to be increased relative to that in control rats when measured on islet RNA. These discrepancies may reflect different methodologies, as the previous study utilized a continuous intravenous infusion of insulin [13], while our studies used intermittent insulin injection. In the current study, however, hypoglycaemia (blood glucose $<3.7 \mathrm{mmol} / \mathrm{l}$ ) was maintained with injections every $12 \mathrm{~h}$ of NPH and Ultralente insulins. In situ hybridization analysis had not been used as extensively for quantitation as Northern and dot blot analysis of whole tissue RNA. Furthermore, measurement of mRNA by in situ analysis is semi-quantitative, and may be complicated by the low abundance of GLUT 2 mRNA relative to proinsulin mRNA. For example, proinsulin mRNA can be readily detected in Northern blots of total pancreatic RNA in a few hours, while analysis of poly $(\mathrm{A}+)$ enriched RNA required several days to visualize GLUT 2 mRNA (data not shown). The results of the current study further suggest that the decrease in glucose transport activity previously noted [13] is not accompanied by changes in gene expression, but may reflect changes in intrinsic activity.

The results of GLUT 2 mRNA quantitation differed when measured on whole pancreatic RNA compared to isolated islet RNA. Northern blotting of RNA from isolated islets suggested that GLUT 2 mRNA increased relative to other islet mRNAs after prolonged fasting or insulin-induced hypoglycaemia. One explanation for the differences noted is that the denominators are different, i.e. total pancreatic RNA vs islet RNA. While both conditions are associated with significant reductions in pancreatic and islet RNA, the increase in GLUT 2 $\mathrm{mRNA} / \mu \mathrm{g}$ islet RNA may result from an increased stability of GLUT 2 mRNA relative to other islet RNA, not apparent when expressed relative to total pancreatic RNA.

Quantitative analysis of islet GLUT 2 protein in fasted or insulin-injected rats has not been previously reported. In contrast to the result for GLUT $2 \mathrm{mRNA}$, following insulin-induced hypoglycaemia, there was a small (39\%) reduction in GLUT 2 protein by Western blot analysis. This modest decrement in GLUT 2 protein after prolonged insulin-induced hypoglycaemia may account for the decrease in glucose transport reported to occur in islets from insulin-infused rats [13]. As glucose transport is reported to be in ten-fold excess of glucose utilization $[3,29]$ however, it appears unlikely that this reduction in GLUT 2 protein would be rate limiting for islet glucose utilization under this condition.

Expression of pancreatic islet GLUT 2 was compared to that in liver in the same experimental animals. The results showed that GLUT 2 mRNA concentrations also did not change in liver under extremes of changes in blood glucose or insulin concentrations. The results with fasted animals differ from previous findings in liver in which a reduction in liver GLUT 2 mRNA was noted [22]. Considering the marked reduction in total liver RNA noted however, our results also suggest a significant reduction in total GLUT 2 mRNA content in liver after fasting. The results with animals subjected to insulin-induced hypoglycaemia however, suggest that hepatic GLUT 2 expression 
is not sensitive to changes in either blood glucose or insulin levels.

While previous studies have utilized fasting, insulin-induced hypoglycaemia, and dexamethasone treatment to record changes in islet Beta-cell gene expression, the current study is unique in that all three experimental conditions were conducted in the same study. This provided two chronic suppressive conditions (fasting and insulin injection) which have low blood glucose in common, but differ by serum insulin levels, and a chronic stimulative condition (dexamethasone treatment) as well. In these experiments extremes of changes in proinsulin mRNA were observed in vivo. There was more than a seven-fold difference between levels of proinsulin mRNA noted after fasting compared to those after dexamethasone treatment. These extremes of proinsulin mRNA levels may represent a minimal estimate of the range of modulation of proinsulin biosynthesis in vivo, as differences in translational rates have also been noted [33-35]. The results of the current experiments are thus consistent with the observations that insulin biosynthesis is modulated by a variety of nutritional and pharmacologic factors, at least in part through alterations of proinsulin mRNA [27, 33-35].

The changes in islet amyloid polypeptide mRNA were strikingly parallel to those in proinsulin mRNA, with more than an eight-fold difference between lowest and highest levels. Consistent with previous observations, islet amyloid polypeptide mRNA levels were reduced after fasting [36, 37], insulin-induced hypoglycaemia [37], and increased with dexamethasone treatment [38]. These results indicate an overall high degree of correlation between proinsulin and islet amyloid polypeptide mRNA levels for all animals $(r=0.974, p<0.001)$. In previous experiments on neonatal rats, we noted that weaning on high carbohydrate vs high fat diets enhanced islet amyloid polypeptide gene expression, as did obesity [39]. These results together suggest that plasma glucose levels are an important determinant of islet Beta-cell islet amyloid polypeptide and proinsulin gene expression, and that these genes might be regulated by similar transcriptional or turnover regulatory mechanisms or both. This was found not to be so for GLUT 2 gene expression.

The results of these experiments are consistent with the concept that the GLUT 2 gene is not regulated by alterations in blood glucose or insulin levels. The results further suggest that modulation of islet GLUT 2 gene expression is not likely to play a role in the chronic adaptive responses in glucose-stimulated insulin secretion. Any participation of this protein in glucose sensing by normal islets, if it exists, would most likely be due to changes in intrinsic activity.

Acknowledgements. The authors wish to thank Ms. J. Wokurka for help in preparation of the manuscript, Cris Welling for technical assistance, and Prof. D.F. Steiner for the rat islet amyloid polypeptide cDNA. Anti-GLUT 2 protein antibody (1608) was the kind gift of Drs. R.Piper and D. James (Department of Cell Biology, Washington University School of Medicine, St.Louis, Mo., USA). This work was supported in part by a grant DK16746 (MAP) and DK38495 (MMM) from the NIH. LK was a recipient of a Juvenile Diabetes Foundation Fellowship Award.

\section{References}

1. Burch PT, Trus MD, Berner DK, Leontire A, Zawalich KC, Matchinsky FM (1981) Adaptation of glycolytic enzymes. Glucose use and insulin release in rat pancreatic islets during fasting and refeeding. Diabetes 30: 923-928

2. Welsh M, Andersson A (1982) Effects of starvation on oxidative metabolism and insulin release by isolated mouse pancreatic islets. Acta Endocrinol (Copenh) 101:227-234

3. Matschinsky FM, Ellerman JE (1968) Metabolism of glucose in the islets of Langerhans. J Biol Chem 243: 2730-2736

4. Heilman B, Sehìn J, Taljedal I-B (1971) Evidence for mediated transport of glucose in mammalian pancreatic $\beta$-cells. Biochim Biophys Acta 241: 147-154

5. Johnson JH, Newgard CB, Milburn JL, Lodish HF, Thorens B (1990) The high $\mathrm{K}_{\mathrm{m}}$ glucose transporter of islets of Langerhans is functionally similar to the low affinity transporter of liver and has an identical primary sequence. J Biol Chem 265: 6548-6551

6. Matchinsky FM (1990) Glucokinase as glucose sensor and metabolic signal generator in pancreatic B-cells and hepatocytes. Diabetes 39: 647-652

7. Magnuson MA (1990) Glucokinase gene structure. Functional implications of molecular genetic studies. Diabetes 39: 523-527

8. Unger RH (1991) Diabetic hyperglycemia: link to impaired glucose transport in pancreatic $\beta$ cells. Science $251: 1200-1205$

9. Tiedge M, Lenzen $S$ (1991) Regulation of glucokinase and GLUT-2 glucose-transporter gene expression in pancreatic Bcells. Biochem J 279: 899-901

10. Best CH, Haist RE (1941) The effect of insulin administration on the insulin content of the pancreas. J Physiol 100: 142-146

11. Chen L, Komiya I, Inman L et al. (1989) Effects of hypoglycemia and prolonged fasting on insulin and glucagon gene expression. Studies with in situ hybridization. J Clin Invest 84: 711-714

12. Bedoya FJ, Matschinsky FM, Shimizu T, O'Neil JJ, Appel M (1986) Differential regulation of glucokinase activity in pancreatic islets and liver of the rat. I Biol Chem 261: 10760-10\%64

13. Chen L, Alam T, Johnson JH, Hughes S, Newgard CB, Unger RH (1990) Regulation of $\beta$-cell glucose transporter gene expression. Proc Natl Acad Sci USA 87: 4088-4092

14. Chen L, Komiya I, Imman L, McCorkle K, Alam T, Unger RH (1989) Molecular and cellular responses of islets during perturbations of glucose homeostasis determined by in situ hybridization histachemistry. Proc Natl Acad Sci USA 86: 1367-1371

15. Giddings SJ, Orland MJ, Weir GC, Bonner-Weir S, Permutt MA (1985) Impaired insulin biosynthetic capacity in a rat model for non-insulin-dependent diabetes. Diabetes 34:235-240

16. Orkand MJ, Permutt MA (1991) Comparative modulations of insulin secretion, pancreatic insulin content, and proinsulin mRNA in rats. Effects of $50 \%$ pancreatectomy and dexamethasone administration. Diabetes 40:181-189

17. Brunstedt J, Nielsen JH (1981) Direct long-term effect of hydrocortisone on insulin and glucagon release from mouse pancreatic islets in tissue culture. Acta Endocrinol (Copenh) 96: 498-504

18. Kawai A, Kuzuya N (1977) On the role of glucocorticoid in glucose-induced insulin secretion. Horm Metab Res 9:361-365

19. Chromczynski P, Sacchi N (1987) Single step method of RNA isolation by acid guanidium thiocyanate-phenol-chloroform extraction. Anal Biochem 162: 156-159

20. Giddings SJ, Carnaghi LR (1988) The two non-allelic rat insulin mRNAs and pre-mRNAs are regulated coordinately in vivo. J Biol Chem 263: 3845-3849

21. Permutt MA, Koranyi L, Keller K, Lacy PE, Scharp DW, Mueckler M (1989) Cloning and functional expression of a human pancreatic islet glucose-transporter cDNA. Proc Natl Acad Sci USA 86: 8688- 8692

22. Thorens B, Flier JS, Lodish HF, Kahn BB (1990) Differential regulation of two glucose transporters in rat liver by fasting and refeeding and by diabetes and insulin treatment. Diabetes 39: 712-719

23. Nishi M, Chan SJ, Nagamatsu S, Bell GI, Steiner DF (1989) Conservation of the sequence of islet amyloid polypeptide in five 
mammals is consistent with its putative role as an islet hormone. Proc Natl Acad Sci USA 86: 5738-5742

24. Koranyi L, Permutt MA, Chirgwin JM, Giddings SJ (1989) Proinsulin I and II gene expression in inbred mouse strains. Molec Endocrinol 3: 1895-1902

25. Sambrook J, Fritsch EF, Maniatis T (1989) Molecular cloning: a laboratory manual, 2nd edn. Cold Spring Harbor Laboratory Press, Cold Spring Harbor

26. McDaniel ML, Colca JR, Kotagal N, Lacy PE (1983) A subcellular fractionation approach for studying insulin release mechanisms and calcium metabolism in islet of Langerhans. Methods Enzymol 98: 182

27. Giddings SJ, Chirgwin J, Permutt MA (1981) The effects of fasting and feeding on preproinsulin messenger RNA in rats. J Clin Invest 67:952-960

28. McNurlan MA, Tomkins AM, Garlick PJ (1970) The effect of starvation on the rate of protein synthesis in rat liver and small intestine. Biochem J 178: 373-379

29. Meglasson MD, Manning CD, Najafi H, Matschinsky FM (1986) Glucose transport by radiation-induced insulinoma and clonal pancreatic $\beta$-cells. Diabetes 35: 1340-1344

30. Ashcroft SJH, Stubbs M (1987) The glucose sensor. In HIT cells is the glucose transporter. FEBS Lett 219:311-315

31. Shibasaki M, Shibasaki Y, Asano T et al. (1990) Over-expression of glucose transporter modulates insulin biosynthesis in insulin producing cell line. FEBS Lett 270: 105-107

32. Matschinsky FM, Ghosh A, Meglasson MD, Prentki M, June V, von Allman D (1986) Metabolic concomitants in pure, pancreatic beta cells during glucose-stimulated insulin secretion. J Biol Chem 261: 14057-14061

33. Giddings SJ, Chirgwin JM, Permutt MA (1985) Glucose regulated insulin biosynthesis in isolated rat pancreatic islets is accompanied by changes in proinsulin mRNA. Diabetes Res 2: 71

34. Brunstedt J, Chan SJ (1982) Direct effect of glucose on the preproinsulin mRNA level in isolated pancreatic islets. Biochem Biophys Res Comm 106: 1383-1389
35. Nielsen DA, Welsh M, Casadaban MJ, Steiner DF (1985) Control of insulin gene expression in pancreatic beta cells and in an insulin-producing cell line, RIN-5F cells. I. Effects of glucose and cyclic AMP on the transcription of insulin mRNA. J Biol Chem 260: 13585-13589

36. Leffert JD, Newgard CB, Okamoto H, Milburn JL, Luskey KL (1989) Rat islet amyloid polypeptide: cloning and tissue-specific expression in pancreatic islets. Proc Natl Acad Sci USA 86: 3127 3130

37. Alam T, Chen L, Ogawa A, Leffert JD, Unger RH, Luskey KL (1992) Coordinate regulation of amylin and insulin expression in response to hypoglycemia and fasting. Diabetes 41: 508-514

38. O'Brien TD, Westermark P, Johnson KH (1991) Islet amyloid polypeptide and insulin secretion from isolated perfused pancreas of fed, fasted, glucose-treated, and dexamethasone-treated rats. Diabetes 40: 1701-1706

39. Koranyi L, Tanizawa Y, Penicaud L, Atef N, Girard J, Permutt MA (1992) Developmental regulation of amylin and insulin gene expression in lean $(\mathrm{Fa} / \mathrm{Fa})$ and obese (fa/fa) Zucker rats. Diabetes 41: 685-690

40. Thorens B, Sarkar HK, Kaback HR, Lodish HF (1988) Cloning and functional expression in bacteria of a novel glucose transporter present in liver, intestine, kidney, and beta-pancreatic islet cells. Cell 55: 281-290

Received: 21 May 1992

and in revised form: 10 August 1992

Dr. M.A.Permutt

Metabolism Division

Washington University Medical School

660 S. Euclid, Box 8127

St. Louis, MO 63110

USA 